\title{
Seismicity and active faulting of the Kanab-Fredonia area of the southern Colorado Plateau
}

\author{
David S. Brumbaugh ${ }^{1}$ \\ Received 19 July 2007; revised 6 December 2007; accepted 24 January 2008; published 23 May 2008.
}

[1] Detailed study of the historic seismicity of the Kanab-Fredonia area adds information to the location of the Colorado Plateau tectonic boundary in this area and to the nature of contemporary seismicity and faulting on this part of the Colorado Plateau. Historic seismicity over 45 years (1959-2004) defines a band of activity which extends through Fredonia, Arizona and into southern Utah around Kanab. The area is dominated by north trending high-angle normal faults. The spatial distribution of epicenters consists of clusters associated with the West Kaibab, Big Springs, and Toroweap-Sevier faults indicating that these faults may be active. Four focal mechanism solutions show BasinRange style high-angle normal faulting on north to north-northwest trending surfaces that are parallel to subparallel in most cases to mapped Quaternary faults. This suggests a present east-west extension occurring on the southern Colorado Plateau for the KanabFredonia area and an expansion of the adjacent Basin-Range province eastward into the plateau as far as the West Kaibab/Big Springs faults. The West Kaibab/Big Springs faults are proposed to be the tectonic boundary of the southern Colorado Plateau in this area since they mark the limit of significant seismic activity that is combined with Basin-Range type faulting.

Citation: Brumbaugh, D. S. (2008), Seismicity and active faulting of the Kanab-Fredonia area of the southern Colorado Plateau, J. Geophys. Res., 113, B05309, doi:10.1029/2007JB005278.

\section{Introduction}

[2] Detailed study of the historic seismicity of the KanabFredonia area adds information to the location and nature of the Colorado Plateau tectonic boundary and of contemporary seismicity and active faulting on this part of the southern Colorado Plateau (Figure 1).

[3] The Colorado Plateau is an uplifted crustal block that is surrounded on three sides by the extensional block faulted terranes of the Rio Grande Rift and Basin and Range provinces. It exists in physiographic and tectonic contrast to its bordering provinces, and its boundaries are defined on the basis of these contrasting characteristics (Figure 2). Wong and Humphrey [1989] presented a detailed look at the seismicity, faulting, and state of stress of the Colorado Plateau. Their study pointed out that the largest historic plateau earthquakes have occurred in northern Arizona, including the 1906, 1910, and 1912 events of $M_{s} 6.0-6.2$ [Bausch and Brumbaugh, 1997]. The $1959 M_{L} 5.75$ Fredonia earthquake of northern Arizona was also noted. Analysis of the Fredonia earthquake as well as the overall

\footnotetext{
${ }^{1}$ Arizona Earthquake Information Center, Northern Arizona University, Flagstaff, Arizona, USA.

Copyright 2008 by the American Geophysical Union. 0148-0227/08/2007JB005278\$09.00
}

seismicity of the Kanab-Fredonia area is the subject of this paper.

\section{Regional Setting}

[4] The area of Arizona to the north of the Grand Canyon is one of the most consistently seismically active parts of the state. Historic seismicity over 45 years (1959-2004) defines a band of activity which extends through Fredonia, Arizona, and into southern Utah around Kanab (Figure 3). The part of this region between the West Kaibab and Toroweap-Sevier faults is considered to be a physiographic part of the Colorado Plateau. However, tectonic elements such as structural style and changes in crustal thickness suggest a transition between characteristics associated with the Basin and Range and those of the Colorado Plateau [Brumbaugh, 1987].

[5] The structural framework of the Kanab-Fredonia area is dominated by north trending high-angle faults: ToroweapSevier, West Kaibab, Pansaugunt and Big Springs (Figure 3). Field work by Jackson [1990] on the Toroweap fault suggests that it has been active in the last 100,000 years, with the most recent indicated surface displacement within the last 4000 years. Exposure of the Toroweap fault where it crosses the Grand Canyon of Arizona has been studied [Karlstrom et al., 2007]. Basalts cut by the fault have been dated and yield displacement estimates of 44 to $60 \mathrm{~m}$ in the last 600,000 years.

[6] Various definitions exist for the definition of an active fault. Certainly a fault which has historic slip or a record of 


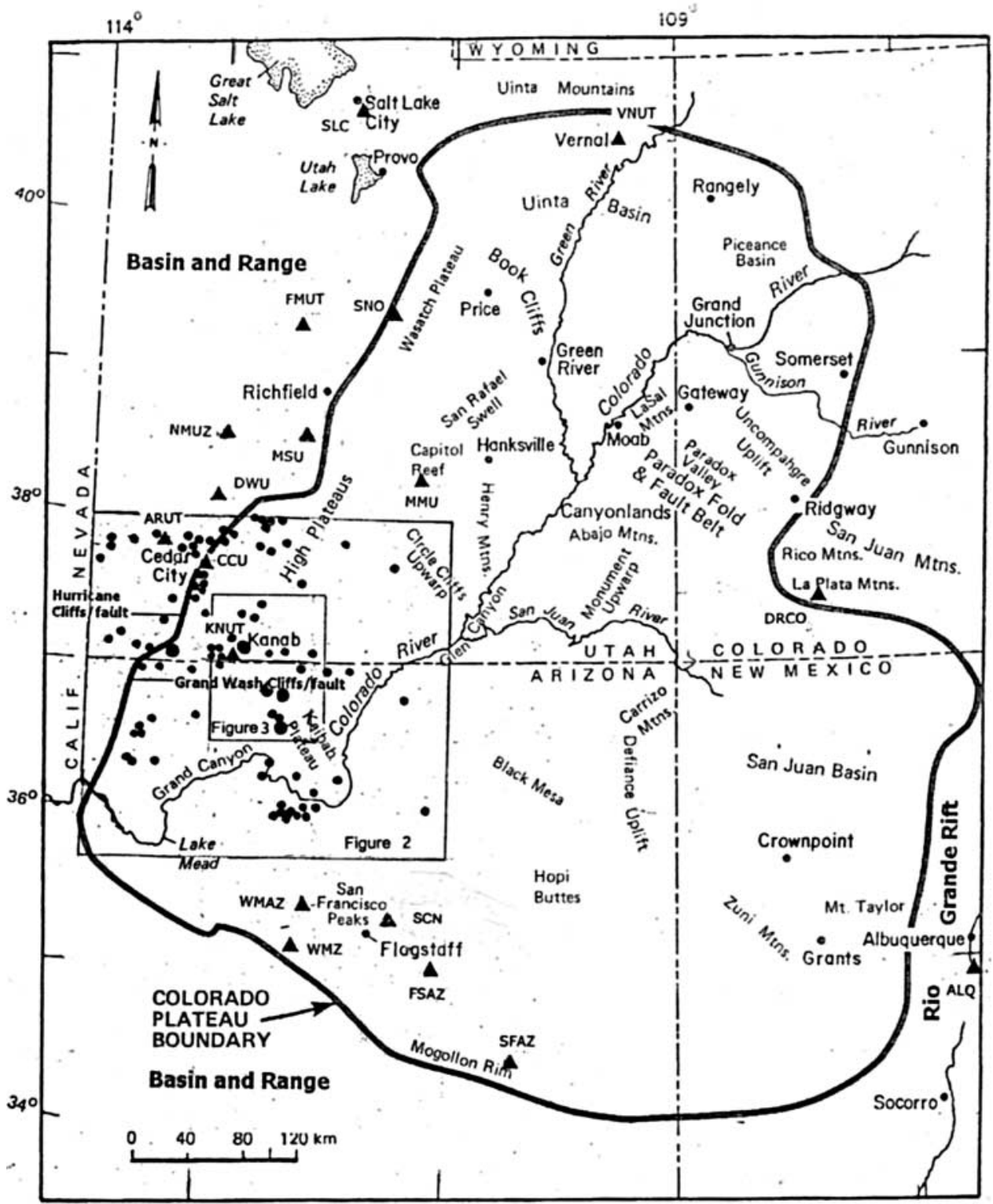

Figure 1. Map of the physiographic boundaries of the Colorado Plateau (dark line). Modified after Wong and Humphrey [1989] (with permission). The two boxes around Kanab show the locations of Figures 2 and 3. Regional seismicity covering the areas of Figures 2 and 3 are shown by black circles. Regional seismic stations that provided data for the study are shown by black triangles with station codes (station locations are listed in Table 4 for all stations used in study). 


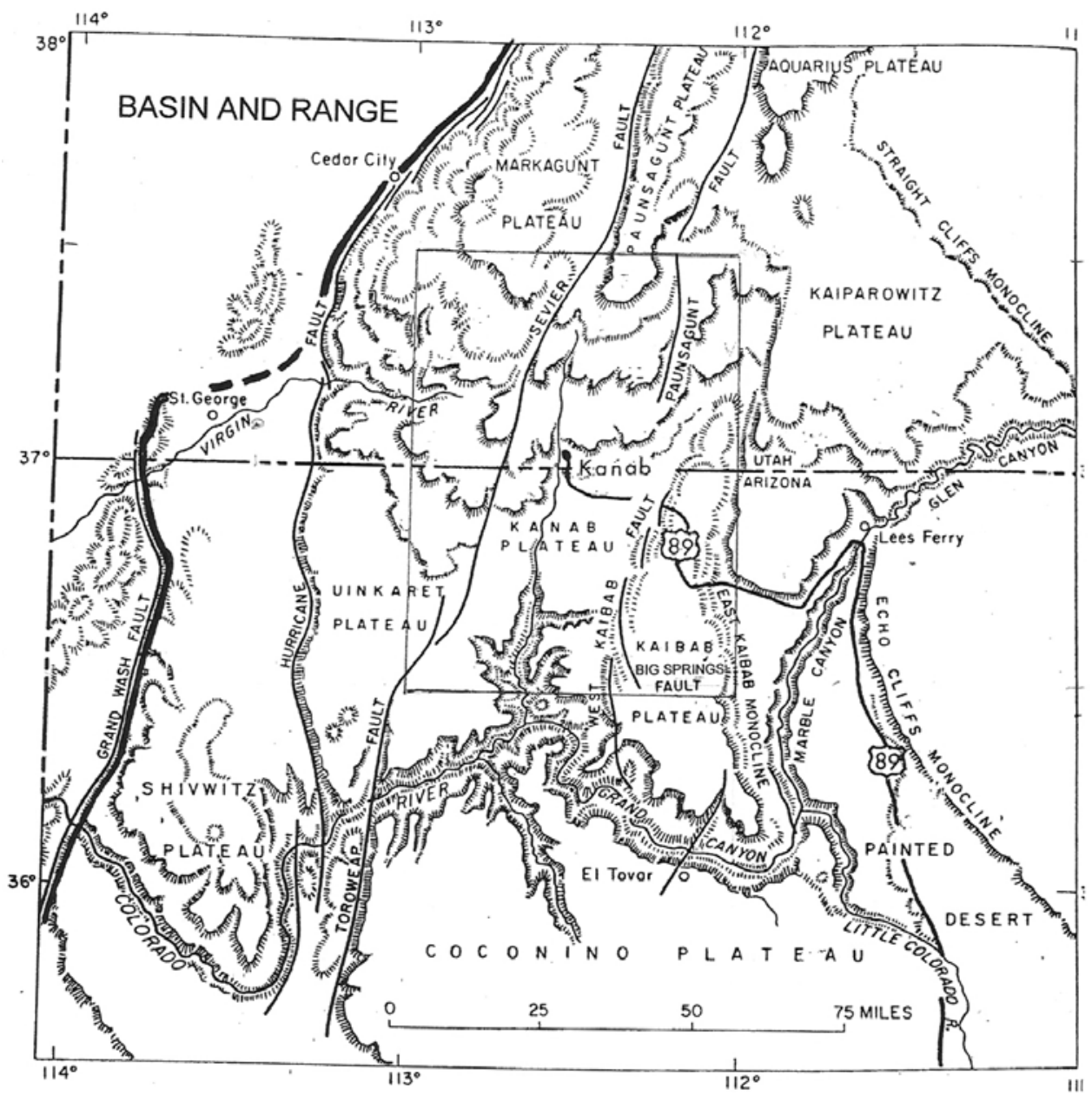

Figure 2. Physiographic map of the southwestern part of the Colorado Plateau (modified after King [1959] and Rigby [1977]). Bold line shows the accepted physiographic boundary between the Basin and Range and the Colorado Plateau for this part of the plateau. Principal faults in the area shown by labeled lines. Box around Kanab shows the location of Figure 3. 


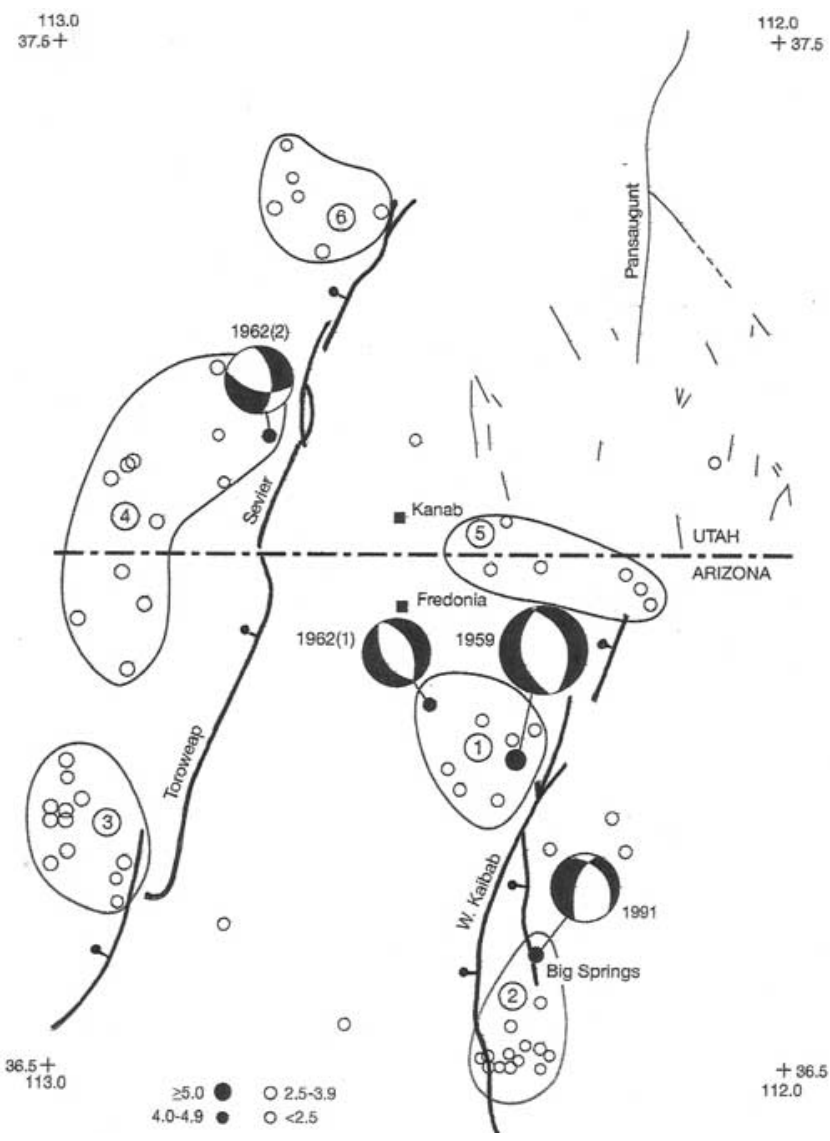

Figure 3. Seismicity and structure map for the KanabFredonia area. The surface traces of mapped faults are shown by lines. Principal faults of this study (e.g., Sevier) are indicated by bold lines with bar and ball symbols showing downthrown side. Beach balls show the focal mechanism solutions of $M_{L} \geq 4.0$ earthquakes (Figure 5). The open and closed circles are epicenter locations proportional to size (Table 1). Geographic clusters of earthquakes are enclosed by outlines and numbers.

active seismicity that can be proved to be directly related to it is an active fault. Lacking this kind of evidence, a number of U.S. government agencies have defined active faults differently: (1) it moved in the last 10,000 years, (2) it moved in the last 35,000 years, (3) it moved in the last 150,000 years, and (4) it moved twice in the last 500,000 years [Yeats et al., 1997]. Clearly, the southern Toroweap fault in northern Arizona can be classed as an active fault in several of these categories.

[7] A history of recent movements similar to that for the Toroweap fault does not exist for the West Kaibab and Big Springs faults. However, Pearthree et al. [1983] show these two faults as being at least likely Quaternary in their latest movements. No focused or detailed study of the seismicity in the area of these faults has so far provided evidence that these faults are active.

\section{Data}

[8] The database for the historic seismicity of the KanabFredonia area was assembled by searching available Internet
Table 1. Kanab-Fredonia Area Seismicity 1959-2004 ${ }^{\mathrm{a}}$

\begin{tabular}{|c|c|c|c|}
\hline Date & OT, UTC & Magnitude & Epicenter \\
\hline $07-21-59$ & 1239 & 5.75 & $36.800 \times 112.370$ \\
\hline $02-15-62$ & 0703 & 2.93 & $36.896 \times 112.399$ \\
\hline $02-15-62(1)$ & 0712 & 4.50 & $36.854 \times 112.484$ \\
\hline $02-15-62(2)$ & 0906 & 4.40 & $37.114 \times 112.711$ \\
\hline $02-15-62$ & 1100 & 2.95 & $37.156 \times 112513$ \\
\hline $04-13-66$ & 0930 & 3.30 & $36.700 \times 112.900$ \\
\hline $05-05-66$ & 0332 & 2.80 & $37.030 \times 112.380$ \\
\hline $05-05-66$ & 0615 & 2.30 & $36.820 \times 112.380$ \\
\hline $08-07-67$ & 1624 & 3.90 & $36.500 \times 112.400$ \\
\hline $03-27-71$ & 0439 & 2.60 & $36.760 \times 112.390$ \\
\hline $07-10-80$ & 0333 & 2.60 & $36.710 \times 112.320$ \\
\hline $07-14-80$ & 1146 & 2.80 & $36.500 \times 112.330$ \\
\hline $07-14-80$ & 1211 & 2.70 & $36.500 \times 112.330$ \\
\hline $07-14-80$ & 1219 & 1.90 & $36.540 \times 112.600$ \\
\hline $07-14-80$ & 1327 & 2.70 & $35.520 \times 112.340$ \\
\hline $07-14-80$ & 1453 & 2.40 & $36.510 \times 112.320$ \\
\hline $01-07-82$ & 1621 & 2.90 & $36.950 \times 112.880$ \\
\hline $02-12-82$ & 1044 & 3.60 & $37.338 \times 112.556$ \\
\hline $03-05-82$ & 0550 & 3.60 & $37.297 \times 112.634$ \\
\hline $04-11-85$ & 0350 & 1.30 & $37.374 \times 112.676$ \\
\hline $04-11-85$ & 0425 & 1.70 & $37.403 \times 112.683$ \\
\hline $04-11-85$ & 0432 & 1.70 & $37.354 \times 112.671$ \\
\hline $09-01-85$ & 1521 & 1.50 & $37.173 \times 112.769$ \\
\hline $01-02-88$ & 2310 & 3.60 & $36.890 \times 112.900$ \\
\hline $05-22-88$ & 1922 & 3.10 & $36.940 \times 112.970$ \\
\hline $06-01-88$ & 0831 & 2.80 & $36.890 \times 112.900$ \\
\hline $02-04-89$ & 1226 & 3.20 & $36.800 \times 112.920$ \\
\hline $03-12-89$ & 0630 & 3.10 & $36.981 \times 112.911$ \\
\hline $07-07-89$ & 0649 & 2.90 & $36.954 \times 112.177$ \\
\hline $09-19-89$ & 0946 & 3.70 & $36.740 \times 112.230$ \\
\hline $09-21-89$ & 1538 & 3.30 & $36.770 \times 112.440$ \\
\hline $04-26-91$ & 1308 & 4.00 & $36.609 \times 112.339$ \\
\hline $05-27-93$ & 0621 & 3.50 & $37.089 \times 112.089$ \\
\hline $10-18-93$ & 1154 & 2.80 & $36.740 \times 113.000$ \\
\hline $04-24-94$ & 1010 & 2.10 & $36.680 \times 112.910$ \\
\hline $04-25-94$ & 0726 & 2.00 & $36.660 \times 112.910$ \\
\hline $03-07-95$ & 2233 & 3.00 & $36.750 \times 112.980$ \\
\hline $04-26-96$ & 0404 & 2.70 & $36.540 \times 112.370$ \\
\hline $08-24-96$ & 2352 & 2.30 & $36.520 \times 112.350$ \\
\hline $08-25-96$ & 1358 & 2.50 & $36.500 \times 112.370$ \\
\hline $08-30-96$ & 0951 & 2.60 & $36.560 \times 112.330$ \\
\hline $12-06-96$ & 1924 & 2.30 & $36.510 \times 112.370$ \\
\hline $01-13-97$ & 0727 & 2.80 & $36.780 \times 112.980$ \\
\hline $01-30-97$ & 1124 & 3.00 & $35.700 \times 113.000$ \\
\hline $07-10-97$ & 0607 & 1.80 & $36.510 \times 112.410$ \\
\hline $07-10-97$ & 1027 & 2.10 & $36.500 \times 112.390$ \\
\hline $07-31-97$ & 0718 & 2.60 & $36.710 \times 112.980$ \\
\hline $09-11-97$ & 0620 & 2.10 & $36.640 \times 112.770$ \\
\hline $09-18-97$ & 0615 & 2.70 & $36.980 \times 112.210$ \\
\hline $09-18-97$ & 2104 & 3.00 & $36.970 \times 112.190$ \\
\hline $10-15-97$ & 1107 & 3.00 & $36.740 \times 112.980$ \\
\hline $11-07-97$ & 0209 & 2.50 & $36.750 \times 113.000$ \\
\hline $11-15-97$ & 0545 & 2.70 & $36.760 \times 112.960$ \\
\hline $01-16-98$ & 0835 & 3.50 & $36.500 \times 112.400$ \\
\hline $02-22-98$ & 1150 & 2.00 & $36.510 \times 112.360$ \\
\hline $02-22-98$ & 1932 & 2.40 & $36.500 \times 112.390$ \\
\hline $06-18-98$ & 0524 & 2.30 & $36.510 \times 112.400$ \\
\hline $02-23-99$ & 0320 & 3.40 & $36.990 \times 112.330$ \\
\hline $10-02-00$ & 0233 & 2.80 & $37.090 \times 112.900$ \\
\hline $03-07-01$ & 0548 & 2.90 & $37.088 \times 112.905$ \\
\hline $01-08-02$ & 1726 & 2.90 & $37.340 \times 112.710$ \\
\hline $04-05-02$ & 0636 & 2.80 & $37.070 \times 112.930$ \\
\hline $04-05-02$ & 1155 & 2.80 & $37.180 \times 112.780$ \\
\hline $04-15-02$ & 0653 & 3.00 & $36.790 \times 112.460$ \\
\hline $07-29-02$ & 0928 & 2.80 & $37.030 \times 112.860$ \\
\hline $03-25-03$ & 2111 & 3.00 & $36.780 \times 112.980$ \\
\hline $09-20-04$ & 0351 & 1.50 & $36.840 \times 112.410$ \\
\hline $09-21-04$ & 1938 & 2.30 & $36.830 \times 112.340$ \\
\hline
\end{tabular}

${ }^{\mathrm{a}}$ Magnitude is Richter $\left(M_{L}\right)$; OT is Universal Time Coordinated origin time. 


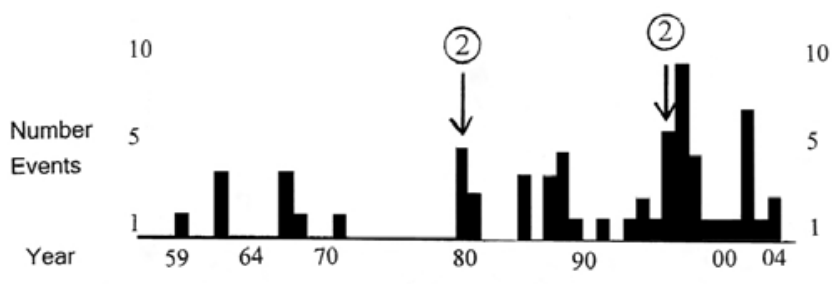

Figure 4. Temporal distribution of Kanab-Fredonia area earthquakes (1959-2004). Circled numbers show the occurrence of temporal clustering for area 2 on Figure 3.

catalogs of the International Seismological Center, U.S. Geological Survey, University of Utah, and the Arizona Earthquake Information Center (AEIC) for the area covered (Figure 3). Therefore for events $M_{L}<4.0$ the epicenter locations of Table 1 are those given in the catalogs. The locations for the earthquakes of $M_{L} \geq 4.0$ have been calculated in this study or are locations that have been calculated previously by the AEIC (see section 5.2). The magnitudes for the historic events of the Kanab-Fredonia area are all Richter $\left(M_{L}\right)$ and are as given in the catalogs listed above (Table 1).

\section{Seismicity of the Study Area}

[9] The spatial and chronologic distribution of tremors in the study area during the time in question (1959-2004) is
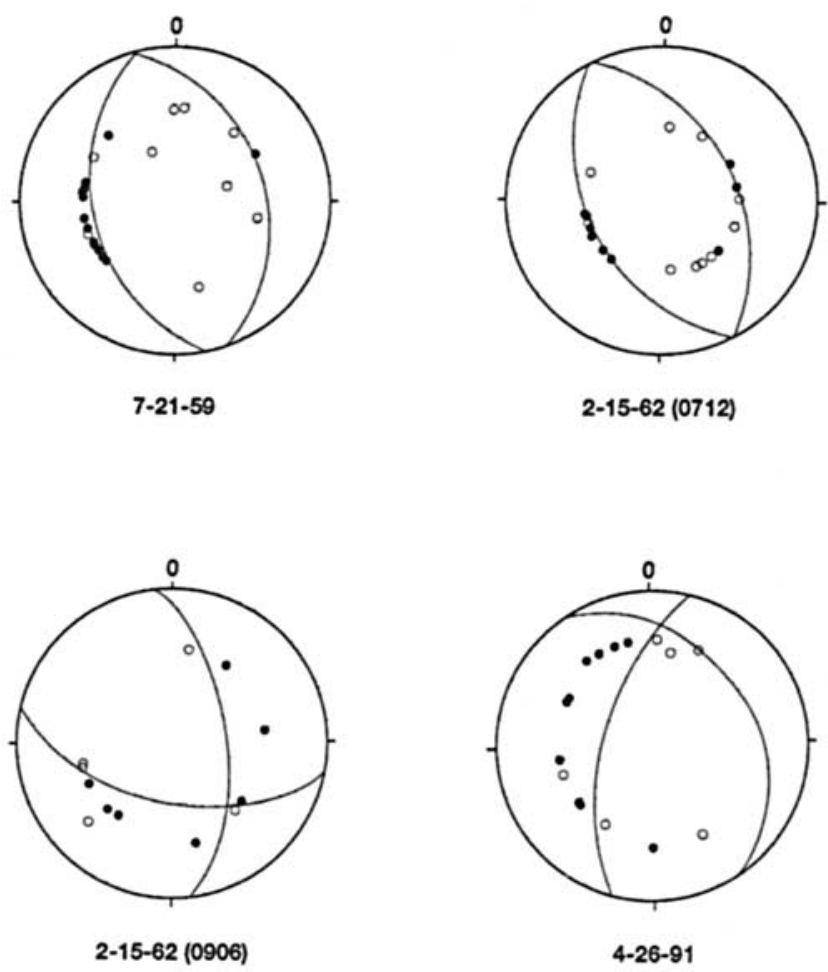

Figure 5. Focal mechanism solutions for the KanabFredonia area. Open circles indicate dilatational first motions; filled circles indicate compressional first motions. Nodal planes represented by great circle traces.
Table 2. First-Motion Focal Mechanism Solution Parameters for $M_{L} \geq 4.0$ Earthquakes of the Kanab-Fredonia Area (1959-2004)

\begin{tabular}{|c|c|c|c|c|c|c|}
\hline Date & $\begin{array}{c}\text { Magnitude } \\
M_{L}\end{array}$ & $\begin{array}{l}\text { Origin } \\
\text { Time, } \\
\text { UTC }\end{array}$ & $\begin{array}{c}\text { Nodal } \\
\text { Plane } 1 \\
\end{array}$ & Slip & $\begin{array}{c}\text { Nodal } \\
\text { Plane } 2 \\
\end{array}$ & $\begin{array}{c}\text { Slip } \\
\text { Vector }\end{array}$ \\
\hline $21-59$ & 5.75 & $1239: 29$ & E & 8 & SW & 258 \\
\hline & & & E & 6 & & 234 \\
\hline 62( & 4. & 90 & 282 & 262 & 353 & 12 \\
\hline $44-26-91$ & 4.0 & $1308: 22$ & $327 / 38 \mathrm{NE}$ & 106 & $196 / 65 \mathrm{SW}$ & 227 \\
\hline
\end{tabular}

heterogeneous. Spatially, the activity in this region consists of clusters comprising the majority of events. Two clusters are spatially associated with the West Kaibab and Big Springs faults, while three more clusters are close to the Toroweap-Sevier fault (Figure 3). A sixth cluster stretches to the northwest from the north end of the West Kaibab fault. Only seven tremors can be found outside of these six clusters distributed across fairly large, otherwise seismically quiescent terranes.

[10] The heterogeneous temporal distribution of tremors is in part due to variation of coverage by seismic stations through time. Before 1962 widely spaced stations in the intermountain west allowed coverage of only larger events (i.e., $M_{L}>4$.0). Therefore occurrence of the $1959 M_{L} 5.75$ tremor is chosen as the beginning of the seismic data set (Table 1). More complete coverage began in 1962 with the Vela Uniform nuclear test monitoring network and has continued to improve with expansion of networks in Utah and Arizona.

[11] Table 1 and Figure 4 have, as their database, tremors located in the Kanab-Fredonia area for 1959-2004. Figure 4 shows that seismicity is chronologically variable for the Kanab-Fredonia area for the time period in question. Three of the six clusters of activity shown in Figure 2 occur spatially associated with the Toroweap-Sevier fault. Only one event larger than $M_{L} 4.0$ occurs near the ToroweapSevier fault, the 1962(2) event (Figure 3). Except for two more tremors, all of the other cluster events near the Toroweap-Sevier fault have been located since 1980, when station coverage improved. Clusters 3, 4, and 6 (Figure 3) show activity spread out all along the fault with temporal spikes in activity comprising the majority of events.

[12] Three of the four tremors $M_{L} \geq 4.0$ are associated with the West Kaibab-Big Springs fault complex. This includes the $M_{L} 4.51962(1)$ tremor as well as the $M_{L} 5.75$ 1959 and $M_{L} 4.01991$ events (Figure 3). The West Kaibab and Big Springs faults also show activity along the length of the fault traces as indicated by clusters 2, 1 , and 5 (Figure 3). Examination of Figure 4 reveals that cluster 2 associated with the West Kaibab and Big Springs fault also exhibits a

Table 3. Velocity-Depth Model for the Kanab-Fredonia Area ${ }^{a}$

\begin{tabular}{cc}
$P$ Wave Velocity, $\mathrm{km} / \mathrm{s}$ & Thickness, $\mathrm{km}$ \\
\hline 4.7 & 1.5 \\
6.2 & 28.5 \\
6.8 & 10.0 \\
8.10 & - \\
\hline
\end{tabular}

${ }^{\mathrm{a}}$ From Brumbaugh [1990]. 
Table 4. Location of Stations Used in This Study

\begin{tabular}{|c|c|}
\hline Station Code & Latitude $\times$ Longitude $^{\mathrm{a}}$ \\
\hline ALQ & $34.942 \times-106.458$ \\
\hline ARUT & $37.788 \times-113.440$ \\
\hline BAR & $32.680 \times-116.672$ \\
\hline BDA & $36.015 \times-114.737$ \\
\hline BRK & $37.873 \times-112.260$ \\
\hline BUT & $46.013 \times-112.563$ \\
\hline $\mathrm{CCU}$ & $37.675 \times-113.069$ \\
\hline CLC & $35.817 \times-117.597$ \\
\hline $\mathrm{COL}$ & $64.900 \times-147.793$ \\
\hline CPCL & $32.729 \times-116.371$ \\
\hline DAL & $32.846 \times-96.784$ \\
\hline DEN & $39.792 \times-105.033$ \\
\hline DLM & $37.606 \times-114.739$ \\
\hline DLT & $34.170 \times-117.810$ \\
\hline DRCO & $37.645 \times-107.783$ \\
\hline DVCL & $35.833 \times-116.102$ \\
\hline DWU & $38.105 \times-112.998$ \\
\hline EUR & $39.483 \times-115.970$ \\
\hline FMUT & $39.218 \times-112.207$ \\
\hline FRE & $36.768 \times-119.770$ \\
\hline FSAZ & $35.069 \times-111.309$ \\
\hline FTC & $34.873 \times-118.893$ \\
\hline GLA & $33.052 \times-114.827$ \\
\hline GSC & $35.302 \times-116.805$ \\
\hline GOL & $39.700 \times-105.371$ \\
\hline ISA & $35.663 \times-118.474$ \\
\hline KNUT & $37.023 \times-112.828$ \\
\hline LCNM & $32.402 \times-106.599$ \\
\hline MHC & $37.342 \times-121.642$ \\
\hline MLNM & $33.415 \times-108.836$ \\
\hline MMU & $38.199 \times-111.294$ \\
\hline MNNV & $8.436 \times-118.148$ \\
\hline MSU & $38.513 \times-112.174$ \\
\hline MWC & $34.224 \times-118.058$ \\
\hline NMUZ & $38.517 \times-112.850$ \\
\hline PAS & $34.148 \times-118.171$ \\
\hline PLM & $33.353 \times-116.862$ \\
\hline $\mathrm{RCD}$ & $44.075 \times-103.208$ \\
\hline REN & $39.540 \times-119.813$ \\
\hline RTNM & $36.729 \times-104.360$ \\
\hline RVR & $33.993 \times-117.375$ \\
\hline $\mathrm{SCN}$ & $35.369 \times-111.543$ \\
\hline SFAZ & $34.739 \times-110.514$ \\
\hline SLC & $40.674 \times-111.848$ \\
\hline SNO & $39.314 \times-111.538$ \\
\hline SRG & $37.882 \times-115.068$ \\
\hline TIN & $37.055 \times-118.228$ \\
\hline TNCL & $34.198 \times-115.950$ \\
\hline TPC & $34.106 \times-116.049$ \\
\hline TUO & $32.347 \times-110.835$ \\
\hline VNUT & $40.509 \times-109.579$ \\
\hline WDY & $35.700 \times-118.843$ \\
\hline WLL & $42.714 \times-73.211$ \\
\hline WMAZ & $35.418 \times-112.215$ \\
\hline WMZ & $35.156 \times-112.326$ \\
\hline
\end{tabular}

${ }^{\mathrm{a}}$ Negative values indicate west.

tendency for temporal clustering with a series of time related events in 1980 and 1996.

\section{Fault Plane Solutions}

\subsection{Fault Plane Analysis}

[13] Four fault plane solutions were constructed from $P$ wave first motions for the $M_{L} \geq 4.0$ events (Figures 3 and 5). Three are associated with seismic activity clustered about the West Kaibab and Big Springs faults, and the fourth is associated with the Toroweap-Sevier fault (Figures 3 and 5 and Table 2). The structure-velocity model used for location of all four tremors is a modified version of the Warren model (Table 3) [Brumbaugh, 1990]. The errors generated from analysis with HYPO71 indicate that the locations and depths for both the 1962 tremors were very well constrained [Brumbaugh, 1990]. The 1991 event had a well-located epicenter, but the depth was not well determined. Although regional station coverage was better in 1991, data from KNUT, less than $20 \mathrm{~km}$ from the 1962 earthquakes, were not available for the 1991 event (Table 4). This has an important effect on depth resolution for the 1991 earthquake. The closest station to the 1991 event (CLU) was $151 \mathrm{~km}$ away from it. The 1991 solution was tested for the depth range of 1 to $23 \mathrm{~km}$, and it was found the range of depths did not change the results of the fault plane solution.

\subsection{Fredonia Tremor}

[14] Earthquakes of $M_{L} \geq 4.0$ are rare in the interior of the Colorado Plateau. On 21 July 1959 a $M_{L} 5.75$ earthquake occurred south of Fredonia. This is the largest tremor to have occurred in the Kanab-Fredonia area as well as one

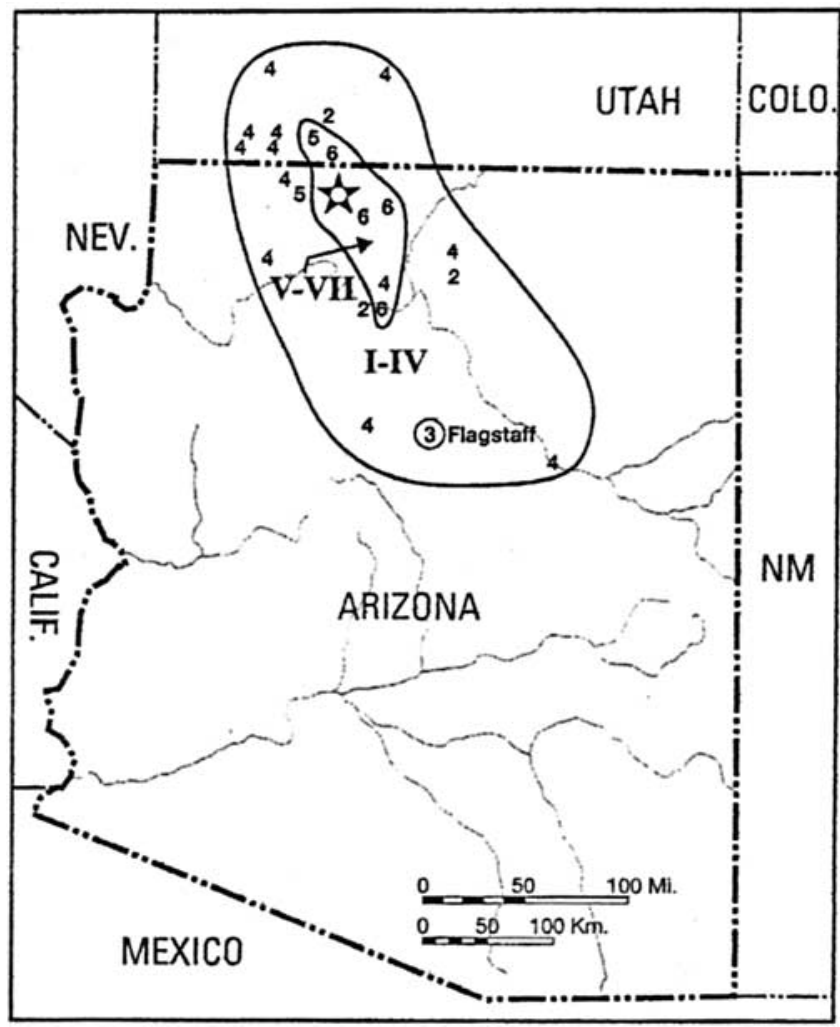

Figure 6. Isoseismal map of the 21 July 1959 earthquake in northern Arizona [from DuBois et al., 1980]. Arabic numbers represent intensities at specific localities. The instrumental epicenter is marked by a star. The depth of focus for this study was calculated by the modified Bath equation from Brumbaugh [2002]: $I_{0}=2.8 \log \left[\left(2.79 A_{V} / \pi+\right.\right.$ $\left.\left.h^{2}\right)\right]+2-\left(6 / 1.2^{h}\right)+\left[\left(6-I_{0}\right) / 6\right]$, where $I_{0}$ is the numerical value of the highest intensity observed, measured on the modified Mercalli intensity scale (MMI); $A_{V}$ is the area of level V intensity on MMI and $h$ is focal depth. 


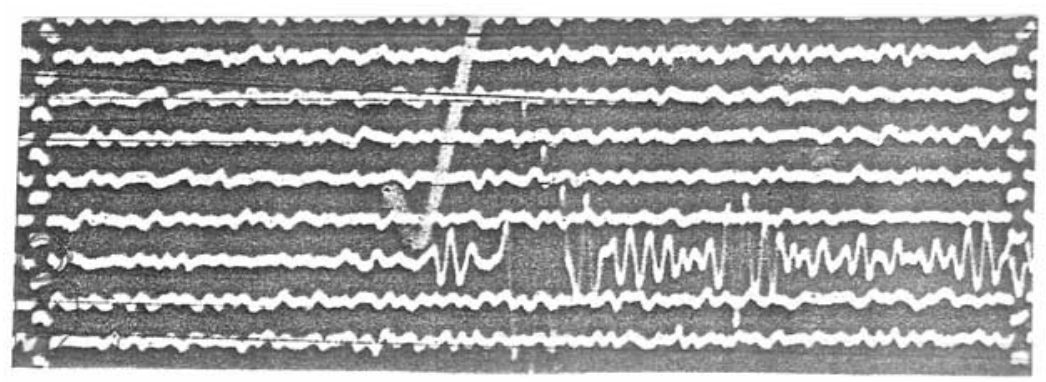

Figure 7. Copy of the long-period vertical record at station COL (College) for the 21 July $1959 M=5.7$ northern Arizona earthquake. Check is at the location of the $P$ wave arrival. The $p P$ wave is shown as the next impulsive arrival.

of the largest in Arizona and in the plateau interior in historic time. Since location and focal depth can be critical to a useful focal mechanism solution, original data were obtained and analyzed to reevaluate these parameters.

[15] The location for the 21 July $1959 M_{L} 5.75$ tremor reported in the literature is from the International Seismological Summary (ISS) (SGA Storia Geofisica Ambiente, 1959, available at http://storing.ingv.it/ISS) at $36.8^{\circ} \mathrm{N} \times$ $112.37^{\circ} \mathrm{W}$. This location lies inside the highest isoseismal contour on the published intensity map (Figure 6) [DuBois et al., 1980]. An analysis of predicted versus observed arrival time differences from original data was performed for the five closest recording stations over a grid of locations centered on the International Seismological Summary location. This included station BDA, which was not part of the data set for the ISS location. The grid points had a spacing of $0.2^{\circ}$ difference in latitude and longitude The result was that the ISS location for the epicenter gave the smallest arrival time differences.

[16] Because of the fact that the closest station (BDA) was $2^{\circ}$ away from the ISS location, instrumental estimates of depth of focus can be predicted to be poor. The ISS depth was given as $0.0 \mathrm{~km}$ (ISS 1959). A depth calculation was performed using intensity data by application of a modified Bath equation [Brumbaugh, 2002]. This method has been shown to have a reliability of $\leq \pm 3 \mathrm{~km}$ focal depth having been tested on 22 western U.S. earthquakes [Brumbaugh, 2002]. The result was a focal depth of $11 \pm 3 \mathrm{~km}$ (Figure 6). This depth was compared to depth analysis using $p P-P$ differential traveltimes. However, the $p P$ arrival for station COL was the only useful data available (Figure 7). Using the velocity-structure model of Table 3 and calculated takeoff angles, the results of $p P-P$ traveltime differentials for a range of depths was calculated for epicenter to COL (Table 5). The COL record shows a $p P-P$ difference of $4.6-$ $5.1 \mathrm{~s}$, which suggests a focal depth of $13-14 \mathrm{~km}$. Thus the depth range used in the focal mechanism analysis was 8 to $14 \mathrm{~km}$, which covers the depth range suggested from both methods of analysis. The variation of the epicenter location by $0.2^{\circ}$ latitude/longitude and focal depth in $3 \mathrm{~km}$ sttif resulted in 75 data points over which these two parameters were evaluated and over which the focal mechanism solution was tested.

[17] A total of 22 stations supplied first motions for the focal mechanism solution of the 21 July $1959 M_{L} 5.75$ tremor (Figure 5 and Table 6). This solution was tested by varying the epicentral location from $35.8^{\circ} \mathrm{N} \times 112.37^{\circ} \mathrm{W}$ by $\pm 0.2^{\circ}$ longitude and latitude while also varying the depth from 8 to $14 \mathrm{~km}$. The range of epicentral locations over the grid coincides with the area of highest ground shaking intensity of modified Mercalli (MM) V (Figure 6). Fourteen of the 22 stations showed no change in $i_{h}$ (takeoff angle) and location on the plot. Seven of the eight remaining stations that did vary in azimuth and $i_{h}$ had a maximum change of $i_{h}$ of less than $1^{\circ}$ and of azimuth of less than $2^{\circ}$ (Figure 8). The nearest station BDA showed no change with variation of focal depth but a difference of $2.2^{\circ}$ azimuth and $6.26^{\circ} i_{h}$ with a change in epicentral location over the grid (Figure 8). These changes did not affect the solution. Thus the range of changes in depth and location did not alter the solution (Figure 5).

\section{Discussion}

[18] The distribution of epicenters for the period 19592004 suggests that the Toroweap-Sevier, West Kaibab, and Big Springs faults or unmapped/subsurface faults related to the general tectonic framework may be active. The nodal planes for all four fault plane solutions indicate normal faulting on north to north-northwest trending surfaces most of which are parallel to subparallel to the mapped fault trends. An azimuthal plot of the nodal planes from these four solutions and an additional pair from the 1992 St. George earthquake to the west of the study area indicate a median direction of $347^{\circ}$ (Figure 9). Since the tectonic framework is dominated by normal faults and the fault plane solutions are predominantly normal, the median direction of trend of the nodal planes suggests a roughly east-west

Table 5. The $p P-P$ Differential Travel Times for Focus to Station College

\begin{tabular}{cc}
\hline Focal Depth, km & $p P-P$ Differential, s \\
\hline 5 & 2.2 \\
10 & 3.6 \\
12 & 4.3 \\
14 & 5.1 \\
16 & 5.8 \\
18 & 6.5 \\
20 & 7.2 \\
\hline
\end{tabular}


Table 6. First Motion Data ${ }^{a}$

\begin{tabular}{|c|c|c|}
\hline Station & $\mathrm{FM} / i_{h}$ & $\mathrm{Az}$ \\
\hline \multicolumn{3}{|c|}{21 July $1959,36.8^{\circ} \mathrm{N} \times 112.37^{\circ} \mathrm{W}, \mathrm{h}=11 \mathrm{~km}$} \\
\hline BAR & +49.1 & 232.0 \\
\hline CLC & +50.0 & 258.5 \\
\hline DLT & +49.1 & 241.0 \\
\hline FTC & +49.1 & 252.0 \\
\hline ISA & +49.1 & 258.8 \\
\hline PAS & +49.1 & 242.5 \\
\hline PLM & +49.1 & 228.3 \\
\hline RVR & +49.1 & 237.1 \\
\hline TIN & +50.0 & 275.0 \\
\hline BRK & +49.1 & 280.8 \\
\hline FRE & +49.1 & 271.9 \\
\hline $\mathrm{MHC}$ & +49.1 & 277.0 \\
\hline REN & -49.5 & 297.3 \\
\hline BDA & -50.5 & 248.4 \\
\hline BUT & -48.6 & 359.2 \\
\hline EUR & +50.0 & 314.4 \\
\hline TUO & -49.1 & 163.9 \\
\hline DAL & -45.4 & 102.5 \\
\hline $\mathrm{RCD}$ & -48.1 & 41.0 \\
\hline WLL & -28.4 & 74.9 \\
\hline $\mathrm{COL}$ & -27.7 & 334.5 \\
\hline SLC & -50.0 & 5.7 \\
\hline $\mathrm{DEN}$ & +49.5 & 60.4 \\
\hline \multicolumn{3}{|c|}{15 February $1962,36.854^{\circ} \mathrm{N} \times 112.484^{\circ} \mathrm{W}, h=26.0 \mathrm{~km}$} \\
\hline ALQ & -49.1 & 109.5 \\
\hline CLC & -50.0 & 257.5 \\
\hline CPCL & +49.1 & 219.0 \\
\hline DRCO & +50.0 & 79.4 \\
\hline DVCL & +50.0 & 251.8 \\
\hline FMUT & -50.1 & 5.2 \\
\hline FSAZ & -50.1 & 151.5 \\
\hline GOL & +49.5 & 60.9 \\
\hline GSC & +50.0 & 247.4 \\
\hline ISA & +50.0 & 258.0 \\
\hline LCNM & +49.5 & 130.8 \\
\hline MLNM & -50.0 & 137.9 \\
\hline MNNV & -50.0 & 291.1 \\
\hline MWC & -49.1 & 241.6 \\
\hline PAS & +49.1 & 241.5 \\
\hline RTNM & -49.5 & 88.7 \\
\hline SFAZ & -50.5 & 145.8 \\
\hline TNCL & +50.0 & 227.9 \\
\hline VNUT & -50.0 & 31.0 \\
\hline WDY & +49.1 & 259.3 \\
\hline WMAZ & -52.8 & 171.3 \\
\hline \multicolumn{3}{|c|}{15 February $1962,37.114^{\circ} \mathrm{N} \times 112.339^{\circ} \mathrm{W}, \mathrm{h}=11.0 \mathrm{~km}$} \\
\hline CLC & +50.0 & 253.3 \\
\hline CPCL & +49.2 & 215.6 \\
\hline DRCO & +50.0 & 83.4 \\
\hline FMUT & -50.5 & 10.6 \\
\hline GSC & +50.0 & 242.6 \\
\hline KNUT & -63.1 & 226.2 \\
\hline LCNM & +49.5 & 131.3 \\
\hline MLNM & -50.0 & 138.2 \\
\hline TNCL & +50.0 & 223.2 \\
\hline VNUT & +50.0 & 34.9 \\
\hline WDY & -49.2 & 255.9 \\
\hline WMAZ & +56.8 & 166.5 \\
\hline \multicolumn{3}{|c|}{26 April $1991,36.609^{\circ} \mathrm{N} \times 112.339^{\circ} \mathrm{W}, \mathrm{h}=1.0-23.0 \mathrm{~km}$} \\
\hline ARUT & +56.8 & 323.6 \\
\hline $\mathrm{CCU}$ & +56.8 & 331.5 \\
\hline CLC & +50.0 & 261.0 \\
\hline DLM & +50.5 & 298.1 \\
\hline DWU & +56.8 & 340.8 \\
\hline GLA & -50.0 & 210.7 \\
\hline GSC & -50.0 & 251.5 \\
\hline ISA & +49.2 & 261.0 \\
\hline MMU & -56.8 & 27.4 \\
\hline MSU & -56.8 & 3.9 \\
\hline
\end{tabular}

Table 6. (continued)

\begin{tabular}{lcc}
\hline Station & $\mathrm{FM} / i_{h}$ & $\mathrm{Az}$ \\
\hline NMUZ & +56.8 & 348.1 \\
PLM & +50.0 & 230.1 \\
SCN & -56.8 & 152.2 \\
SNO & -50.5 & 13.0 \\
SRG & +50.5 & 301.1 \\
TPC & +50.0 & 231.6 \\
WMZ & +56.8 & 179.6 \\
\hline
\end{tabular}

${ }^{\mathrm{a}} \mathrm{FM}$, first motion (positive values, compression; negative values, dilatation); $i_{h}$, takeoff angle; Az, epicenter to station azimuth.

direction of extension for this portion of the Colorado Plateau.

[19] Active faulting in the Kanab-Fredonia area as deduced from analysis of historic seismicity fits the style and pattern of faulting seen in the Basin-Range province to the west of the physiographic boundary of the plateau (Grand Wash and Hurricane faults, Figure 2). This pattern of seismicity, active normal faulting and extension within the physiographic boundaries of the southern Colorado Plateau, has been documented as far south as the Mogollon Plateau region of the Colorado Plateau and extends in a continuous band through the Grand Canyon area to the Kanab-Fredonia region. This band of seismicity and associated faulting has been termed the Northern Arizona Seismic Belt [Brumbaugh, 2008; Wong and Humphrey, 1989; Lay et al., 1994; Brumbaugh, 2005]. The overlap of seismicity and normal faulting onto the physiographic plateau interior supports the picture previously suggested [Brumbaugh, 1987; Best and Hamblin, 1978] of extensional tectonism advancing

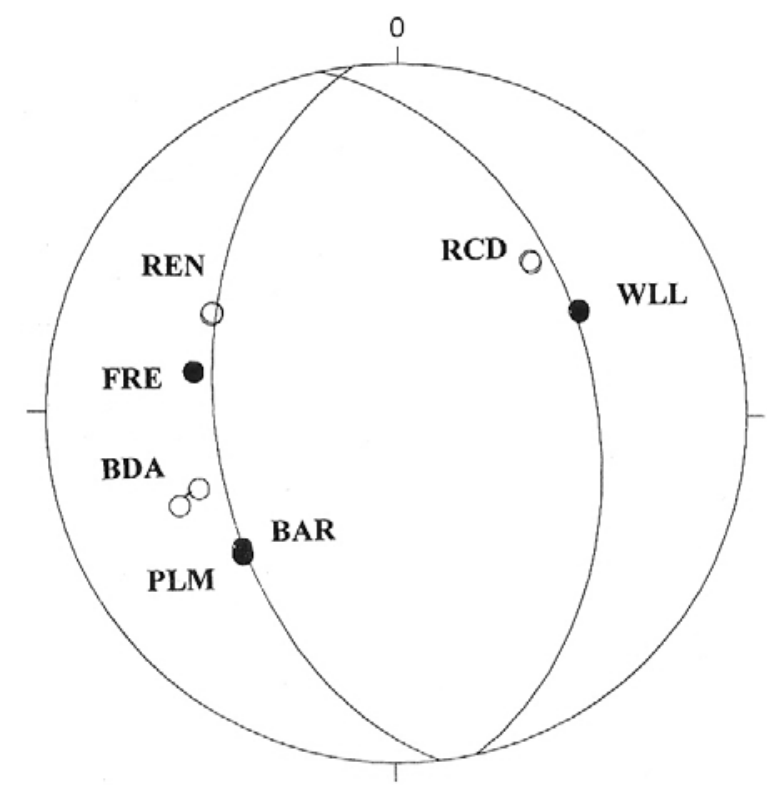

Figure 8. Variation of station plot locations with change in epicenter/depth for the 21 July 1959 earthquake. Shown are the greatest change in plot position for the closest station (BDA), which had the greatest variance, and several stations controlling the focal plane locations. Locations for stations shown by code are given in Table 4 . 


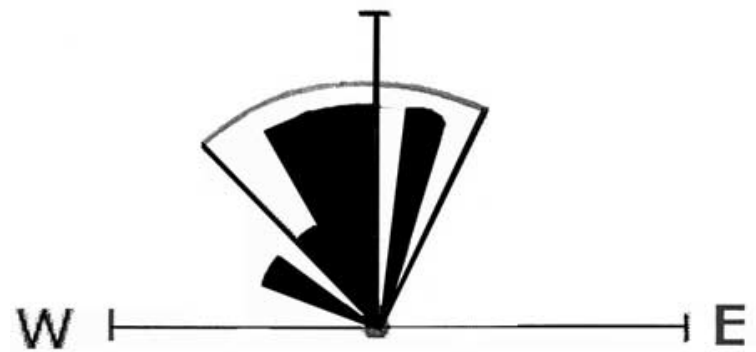

Figure 9. Trend of fault planes and nodal planes from the fault plane solutions for the Kanab-Fredonia area. Filled in pie sectors are the nodal plane trends; open pie sector shows fault trends.

on a broad front into the plateau and expanding the area of the Basin and Range province at the expense of the plateau.

[20] The physiographic boundary of the plateau in the Kanab-Fredonia region is clearly marked by the elevation changes in the vicinity of the Hurricane fault (Figure 2). However, the overlap of seismicity and Basin-Range style high-angle extensional faulting from the physiographic boundary and into the plateau interior in the Kanab-Fredonia area suggests that the Colorado Plateau tectonic boundary marked by the limit of seismicity and style of faulting belongs at the location of the West Kaibab-Big Springs fault system.

\section{References}

Bausch, D. B., and D. S. Brumbaugh (1997), Relocation study of early Arizona earthquakes: Events of 1906, 1910, and 1912, Rep. SR97, 110 pp. Ariz. Earthquake Inf. Cent., Flagstaff, Ariz.

Best, M. G., and W. K. Hamblin (1978), Origin of the northern Basin and Range Province: Implications from the geology of its eastern boundary, in Cenozoic Tectonics and Regional Geophysics of the Western Cordillera, edited by R. B. Smith and G. P. Eaton, Mem. Geol Soc. Am., 152, 313-340.
Brumbaugh, D. S. (1987), A tectonic boundary for the southern Colorado Plateau, Tectonophysics, 136, 125-136, doi:10.1016/00401951(87)90335-0.

Brumbaugh, D. S. (1990), Depth of the Fredonia area earthquakes of 15 February 1962, Bull. Seismol. Soc. Am., 80, 1762-1764.

Brumbaugh, D. S. (2002), Depth analysis of historic seismicity using intensity data with special reference to Arizona events, Eos Trans. AGU, 83(47), Fall Meet. Suppl., Abstract S11B-1145.

Brumbaugh, D. S. (2005), Active faulting and seismicity in a prefractured terrane: Grand Canyon, Arizona, Bull. Seismol. Soc. Am., 95, 15611566, doi:10.1785/0120040096.

Brumbaugh, D. S. (2008), Seismicity and tectonics of the Blue Ridge area of the Mogollon Plateau, Arizona, Bull. Seismol. Soc. Am., in press.

DuBois, S. M., A. W. Smith, N. K. Nye, and T. A. Nowak (1980), Arizona earthquakes 1776-1980, Bull. Ariz. Bur. Geol. Min. Technol., 193, 456 pp.

Jackson, G. (1990), Tectonic geomorphology of the Toroweap fault: Implications for transgressions of faulting on the Colorado Plateau, Ariz. Geol. Surv. Open File Rep., 90-94, 1-66.

Karlstrom, K. E., R. S. Crow, L. Peters, W. McIntosh, J. Raucci, L. J. Crossey, P. Umhoeffer, and N. Dunbar (2007), ${ }^{40} \mathrm{Ar} /{ }^{39} \mathrm{Ar}$ and field studies of Quaternary basalts in Grand Canyon and model for carving Grand Canyon: Quantifying the interaction of river incision and normal faulting across the western edge of the Colorado Plateau, Geol. Soc. Am. Bull., 119, 1283-1312, doi:10.1130/0016-7606(2007)119[1283:AAFSOQ] 2.0.CO;2.

King, P. B. (1959), The Evolution of North America, 190 pp., Princeton Univ. Press, Princeton, N. J.

Lay, T., J. Ritsema, C. J. Ammon, and T. Wallace (1994), Rapid sourcemechanism analysis of the April 29, 1993 Cataract Creek $\left(M_{w}=5.3\right)$, northern Arizona earthquake, Bull. Seismol. Soc. Am., 84, 451-457.

Pearthree, P. A., C. M. Menges, and L. Mayer (1983), Distribution, recurrence, and possible tectonic implications of late Quaternary faulting in Arizona, Ariz. Bur. Geol. Min. Technol. Open File Rep., 83-20, 51 pp.

Rigby, J. K. (1977), Southern Colorado Plateau, 148 pp., Kendall/Hunt, Dubuque, Iowa.

Wong, I. G., and J. R. Humphrey (1989), Contemporary seismicity, faulting, and the state of stress in the Colorado Plateau, Geol. Soc. Am. Bull., 101, 1127-1146, doi:10.1130/0016-7606(1989)101<1127:CSFATS >2.3.CO;2.

Yeats, R. S., K. Sieh, and C. R. Allen (1997), The Geology of Earthquakes, 568 pp., Oxford Univ. Press, New York.

D. S. Brumbaugh, Arizona Earthquake Information Center, Northern Arizona University, Box 86011-4099, Flagstaff, AZ 86001, USA. (david.brumbaugh@nau.edu) 